Kallio, Kirsi Pauliina, Häkli Jouni, Pascucci Elisa

\title{
Refugeeness as political subjectivity: Experiencing the humanitarian border
}

\begin{abstract}
Building on the idea of the humanitarian border, the paper seeks to theorise its fluctuating geographies as growing from particular governmental strategies, yet shaped by social elements operating beyond the migration regime. We approach the humanitarian border topologically as a relational space experienced by refugee-subjects and constituting of regulations, techniques, tactics and (counter)practices that have emerged, and keep evolving, when people seek asylum in different parts of the world. We suggest that one of the asylum seekers' key assets in navigating the humanitarian border is agency based on subjective relatedness with the figure of the refugee. Hence, we direct our analytical attention to experiences of refugeeness that we have studied empirically in the context of forced migration in Finland and Jordan. The analysis identifies asylum seekers' ambivalent emotions and agencies, foregrounding political subjectivities both in the context of immobile life in Amman, and on the move along the Western Balkans route. This reveals the dual politics of the humanitarian border, at once constitutive of and constituting in encounters between asylum seekers and its other actors. In conclusion, the paper makes two suggestions regarding the study of refugeeness as political subjectivity and the topological theorisation of the humanitarian border.
\end{abstract}

\section{Introduction}

In a world of multiplying conflict, asylum seeking has ceased to be an exceptional life situation or basis for identity. According to the United Nations High Commissioner for Refugees (UNHCR), the number of refugees is currently over 28 million and that of forcibly displaced people more than 68 million (Global Trends, 2017). Yet, while becoming a refugee at some stage of one's life is more common than ever, for each person involved the situation is always unique. Those who journey to seek asylum in another country go through a process that shows them what it means to be a refugee, in their particular case. To some extent, this happens also to people who shift from one refugee position to another, for example, when people who were born in exile move on to seek international protection in another country.

While the circumstances in and through which people move to seek refuge vary greatly, they share characteristics that recent literature has started to address through the concept of humanitarian border. This approach, inspired by Foucauldian theorisations of governmentality, was originally introduced by William Walters (2011) who suggested it as a methodological inroad for studying how particular forms of knowledge materialise in humanitarian institutions and activities, and for identifying the constitutive role that politics has in these bordering practices. Specifically, he wanted to draw attention to the Janus-faced nature of humanitarian migration control as both provision of support and protection, and selective sorting between the deserving and undeserving. Verdirame and Harrell-Bond (2005: xvii) have identified this two-facedness in the "great disparity between the 'face' of humanitarian aid as it is viewed by its donors and the 'face' of the same aid as seen by its 
beneficiaries". As Walters (2011: 145) puts it, the humanitarian border mingles a "politics of alienation with a politics of care, and a tactic of abjection and one of reception".

For us the humanitarian border appears as a fruitful concept because, while growing from particular governmental strategies, its fluctuating geographies are also shaped by social elements operating beyond the reach of state strategies (see also Walters, 2011). To probe further into this somewhat neglected dimension, we approach the processual humanitarian spaces from the perspectives of those involved in its practices as refugee-subjects. By analysing asylum seekers' experiences of encounters with the humanitarian border, we delve deeper into its social constitution, yet keeping in mind the governmental mechanisms that seek to regulate and manage the evolving 'borderings'. Our approach differs from a traditional Foucauldian approach in that, instead of portraying refugees primarily as subjected subjects with little agency, our aim is to identify political subjectivities that arise from their active involvement in the practices that constitute the humanitarian border. In so doing, we wish to foreground the ways in which encounters with migration management requires migrants to enact and retain a multi-faceted sense of self in order to successfully navigate the bureaucracy. The analysis builds on and develops further our previous work, with two theoretical underpinnings.

First, we begin from the idea that one of the asylum seekers' key assets in encountering and acting upon the humanitarian border is agency based on subjective (and shared) relation with the figure of the refugee (Häkli et al., 2017). In contrast to readings that take refugeeness merely as a dominating identity structure, we consider it a form of political subjectivity operating on the possibility of experiencing a distance between one's sense of self and the refugee identity proposed by the humanitarian discourses and practices that asylum seekers encounter. For us subjectivity is a theoretical notion that refers to the irreducibility of the subject to any identity or subject position, the 'refugee' included. It is precisely the openendedness of subjectivity that sustains the political in everyday life, that is, the capacity to manoeuvre and depart from routines in mundane situations (Häkli and Kallio, 2018).

Second, in connection with our focus on refugeeness as political subjectivity, we understand the humanitarian border as a topologically constituting constellation of regulations, techniques, tactics and (counter)practices that has emerged and keeps evolving when people seek asylum in different parts of the world. It involves not only institutional actors working for humanitarian NGOs, the UNHCR and the states, but also many informal actors who provide transportation and other services to the people on the move, as well as the refugees themselves, leaning on their communities and networks. Rather than a governance regime per se, we thus consider the humanitarian border as a social space constituted when and where the regime and the asylum seekers encounter. With the topological approach, we accentuate the social, mobile and constantly changing nature of this border, which is not to ignore the many stabilised territorial elements embedded in it (Häkli and Kallio, 2014; Kallio and Häkli, 2017).

In this paper, we pay particular attention to the humanitarian border constellation as coming into existence through the immobilities that characterise the experience of refugees within the Middle East, and through the powerful acts of border crossing in the Western 
Balkans route during the summer and autumn of 2015. While the latter undoubtedly posed a challenge to humanitarian governance and border enforcement, we argue, in both cases a reconfiguration, rather than suspension or erasure, of the relational bundles through which humanitarianism and borders intertwine took place.

The paper draws on fieldwork in countries that occupy very different positions within the global geographies of refuge, as well as in relation to the routes that characterised the socalled 2015 'refugee crisis' in Europe: Finland and Jordan. In the latter, the vast majority of the refugee population are Syrians who have official legal recognition but find themselves in a condition of immobility and socio-economic uncertainty. In this context, our inquiry into humanitarian bordering focuses on the emotionally charged experiences, and often strategically connotated acts, of soliciting, receiving, or being partially denied assistance by international humanitarian agencies. In the Finnish study, we draw prevalently from interviews with a young, male and mobile demographic of asylum seekers from Iraq, mainly from Baghdad and other urban areas in the centre and south of the country. Here, the humanitarian border materialised primarily through embodied experiences of border crossing along the Balkans route.

The paper proceeds so that we first introduce our understanding of the humanitarian border as a topological constellation and, in relation to this, refugeeness as political subjectivity. These two conceptual sections are followed by a description of the studies and their contexts, after which we move to the empirical analysis. Analysing emotionally charged experiences stemming from encounters with humanitarian bordering practices, we trace refugeeness as political subjectivity that exposes the humanitarian border to asylum seekers through their abiding and resistant, visible and hidden agencies. In conclusion, we discuss our findings on refugeeness and the humanitarian border, and propose new lines of inquiry for further research.

\section{Humanitarian border as a topological constellation}

The concept of the humanitarian border suggests that some commonalities characterise migration connected with the international aid system. Yet, it does not propose to generalise migration situations. On the contrary, the approach underlines geographical variation and specificity; in each place and case, bordering practices are mobilised by a different set of actors who may seek to maintain, reproduce or transform the boundaries that at once divide and unite people and their lived realities in specific ways (Walters, 2011; Williams, 2016). In distinction from territorial boundaries, such as state borders, these practices draw in people and cultures scattered in space and time. Hence, the humanitarian border is ambiguous in regard its spatiality. One cannot simply stand at or step over the ceaselessly transforming malleable constellation. Its appearance is, then, far from a fence or a wall even if some practices of migration control may manifest it through such elements.

Recent research has convincingly shown how states, in particular, exert their power at a distance to control and redirect migration flows in different territorial border zones. Working at the borderlands of southern Arizona, Williams (2016) emphasises the moral, ethical and political implications of humanitarian care, as it comes to function as a technology of border enforcement. Drawing attention to the dominant Northern/Western approach, Lee (2013) 
has looked into the policing practices related to human trafficking from a Southern perspective, showing how they effectively hinder the movement of 'risky' populations. Besides policing, migration control may include spectacular practices of securitisation and militarisation that hide from view quieter daily practices of exclusion and confinement (M ountz, 2015). Vaughan-Williams (2015) draws from Derrida's zoopolitical critique to argue that, by distinguishing between irregular migrants and regular citizen-subjects, humanitarian practices related to contemporary EU border security create dividing lines within humanity itself. As one concrete example of this dehumanisation, Mitchell and Sparke (2018, p.2) draw attention to how "hotspot geopolitics [...] imposed a mix of coercive immobility and mobility together in ways that undermine efforts to construct embodied spaces of migrant safety". Further, Tazzioli (2016) has studied how the operations M are Nostrum and Triton have transformed the Mediterranean into a space of migration governmentality that builds upon a politics of visibility (also Little \& Vaughan-Williams, 2016; Stierl, 2017).

Showing how the humanitarian border constitutes topologically in practices related to migration governance, this scholarship also foregrounds it as a paradoxical space that mingles humanitarian assistance with social sorting. From a systemic perspective, sorting is typically justified by the claim that the legitimacy of the international refugee policy requires that assistance is granted only to those legally entitled to it and who need it the most.

Nevertheless, from the perspective of asylum seekers the constant demand to prove being 'worthy refugees' may feel dehumanising (Darling, 2009): those in need of help may only receive help when identified as in need of help by those with the means to help them. In this regard, the humanitarian border turns into a temporal life condition that, "by placing migrants in a state of transience [...] prevents them from settling [anywhere]" (Rygiel, 2011: 5, also Verdirame and Harrell-Bond, 2005).

Hence, whereas for the migration regime the humanitarian border constitutes as an adaptable and almost ubiquitous system, present where and whenever migrants seek to make their cases for humanitarian assistance, from the migrants' vantage point it is an indefinite life situation that is both spatially and temporally 'sticky'. This means that in seeking to pass through the humanitarian border, migrants are exposed to experiences of encounters with it over a long period of time, in various geographical locations, and with varying intensities. M oreover, refugee trajectories typically involve both mobility and immobility, as "there are variable degrees of stickiness at work in our ever-changing, highly fluid world" (M urphy, 2012: 170). Therefore, it is important to understand "the characteristics of systems associated with stickiness - where sticky characteristics come from, how and why they work, and what their consequences are" (ibid.).

In this spirit, we conceive of the humanitarian border as a malleable and sticky space that is spatially and temporally extensive, yet unevenly present to the people involved in its practices. As a topological constellation, it bundles together people, sites, organisations, policies, institutions, economies, ideologies, discourses, events, places, natural formations, and objects. Territories and physical borders, too, partake in this topology as states and supranational polities often carry out their sorting practices in the form of border enforcement. Defying a singular spatial logic - like territoriality, network or fluidity - the border is composed by social relations, encounters and practices mobilised at the interface 
between migration control, humanitarian aid, and forced migration. This dynamism defines where the border exists, for whom, how it comes about, and what it is like in each particular context (cf. Walters and Lüthi, 2016: 361, on topological spatiality see Häkli and Kallio 2014, Kallio and Häkli 2017).

Importantly, the ambiguities of the humanitarian border open up possibilities for migrant agencies that contribute to its transformation. The fact that the humanitarian border shapes up differently depending on the context of migration and the actors involved decentres its systemic aspects. Moreover, as de Vries (2016) aptly points out, practices of governance and resistance are relational and co-constitutive so that, in its own practices, humanitarian bordering also contains the seeds to its resistance. By turning next to asylum seekers' political subjectivities related to their emotionally charged experiences, we trace the migrants' active negotiation of, rather than passive conforming to, humanitarian bordering (see also Scheel, 2013; Fontanari, 2015; Walters and Lüthi, 2016).

\section{Refugeenessin the humanitarian border}

Research on refugee identities has shown that they do not form univocally but rather gain meaning and significance contextually, and more often than not, are experienced in contradictory terms (Hadjiyanni, 2002; Grabska, 2006; Ludvig, 2016). It makes a difference whether refugee identity is negotiated, for example, in protracted displacement, or as part of conflict-induced humanitarian migration and temporary provision of international protection. In existing scholarship, much attention has been paid to subjectifying subject positions among forced migrants, that is, "a technology of government that works through the construction of certain forms of refugee subjectivities" (Olivius, 2014: 43). Here the emphasis is on the negative consequences of asylum seekers having to adapt to a refugee identity that, when internalised, subjugates those who come into contact with the international refugee regime (Lacroix 2004; Latif 2008). This reading inscribes the refugee subject with dependence, passivity and subordination (e.g. Luker, 2015; Ong, 2003). Some scholars inspired by Agamben go as far as to view the abjected figure of the asylum seeker as an embodiment of 'bare life' (Darling, 2009; Diken and Laustsen, 2005; Vaughan-Williams, 2015).

The emphasis on suppressive aspects has been criticised by authors concerned with the ways in which this portrays refugeeness as a predetermined identity construction imbued with voicelessness (e.g. Nyers, 1998; Soguk, 1999; Walters, 2008). While subjection is an important facet of the refugee situation, its overemphasis conceals possibilities for political agency, reproducing the predominant view of "migrants as passive and helpless beings" (Walters 2008, 188). In agreement with this criticism, our analytical approach emphasises the humanitarian border from the perspective of asylum seekers, with specific interest in their capacities and strivings to take part in and influence this evolving space. With the term 'refugeeness' we refer to the political dynamism and empowering potential of refugee subjectivities (Häkli and Kallio, 2014; Häkli, Pascussi and Kallio 2017; see also Owens, 2012; Rossdale, 2015; de Vries, 2016).

Drawing from our previous research on political subjectivity, we understand refugeeness as the asylum seekers' capacity to experience a distance between their sense of self and the 
figurations of the refugee engendered in encounters with different elements of the humanitarian border (Häkli and Kallio, 2014, 2018). This subjective relatedness with but irreducibility to refugee identities, we argue, is at the root of experiences through which forced migrants and asylum seekers may become attentive to their positions and shared grievances, and ultimately, mobilise individually and collectively (cf. Baines, 2015; Isin, 2012; Sparke and M itchell, forthcoming; see also Bayat, 2010 on subaltern subjects more generally in the M iddle East). Hence, for us refugeeness as subjectivity is not about technologies of governmentality or internalised identities, but rather it is the condition of possibility for political agency (Häkli et al., 2017).

To trace refugeeness as political subjectivity, we pay particular attention to issues and events in which our participants have had things at stake in their implicit or explicit selfdefinition as a refugee. We consider these events as instances where asylum seekers often become attentive towards the subordinating subject positions that becoming a refugee may entail. More concretely, in our engagements with the research participants we are interested in expressions of emotions, whether these be, for example, feelings of fear in places of origin, distressing moments related to challenging situations during journeys, tacit awareness about critical moments in gaining refugee status, or cognitive investments to learning about possibilities of settling into a place of destination. For us such emotion-laden situations are important because they foreground the asylum seekers' political subjectivities and reveal how refugeeness arises from their encounters with humanitarian bordering. In this regard, we are less concerned with theorising emotions as such, and instead employ the notion as a methodological concept that, often reflecting experienced ambivalences, highlights the fundamentally intersubjective nature of emotions (Holmes, 2015; Sánchez 2012). As Williams and Boyce (2013) point out, the collective aspect of emotional life is often captured through the notion of affect. Yet, for conceptual clarity, and echoing Ahmed's

(2004: 10) conception of the productive "sociality of emotions", in this paper we focus on the experience of emotions and emotional ambivalence as a "shared attribute of all migration [...] closely related to questions surrounding identity" (Gekeler \& Howarth, 2014:

\section{9-190).}

Together our focus on the humanitarian border as a topological constellation and our understanding of refugeeness as political subjectivity pave way for an analysis that highlights the encounters between asylum seekers and various other actors involved in humanitarian bordering, and the varying intensities that characterise these encounters. The humanitarian border is topological precisely in the sense that the practices of migration control, asylum, and humanitarian provision make it both temporally and spatially extensive, yet its presence in asylum seekers' lives remains uneven and thus experienced. In this sense, it is a potentially ubiquitous but discontinuous and fluctuating social space that is difficult to locate definitively. Therefore, in analytical terms we are particularly interested in tracing emotional intensities and ambivalences in our research participants' experiences, as for us these indicate that there are powerful political subjectivities at play in their attempts to navigate in and through the humanitarian border.

\section{Studying refugeeness with asylum seekers}


The analysis presented in this paper draws from in-depth interviews with refugees in Finland, including interviews with individuals (seven young men from Iraq and Somalia) and families (five Afghan families) carried out during the winter of 2016-2017, as well as more ethnographically-orientated fieldwork with Syrian refugees living in the Amman and Zarqa urban areas in Jordan, conducted by one of the authors (Pascucci) between February and September 2017.

The participants in Finland had entered the country as part of the 2015 mass movement in Europe, with the exception of one refugee involved in humanitarian aid practices as a volunteer. Finland received asylum seekers mostly from Iraq (20 485), Russia (6 247, mostly other than Russian citizens), Afghanistan (5 214, including Afghans from Iran) and Somalia (4 027) (M igri, 2017). While people came from varying social and political conditions, young men from urban areas in the centre and south of Iraq formed a vast majority, and are therefore visibly present in our study.

In Jordan, we draw on ethnographic conversations and unstructured interviews with Syrian refugees who had lived in the country from two to five years, having left Syria due to the armed conflict that followed the 2011 uprising. Significantly, female voices are more represented than in our fieldwork in Finland, reflecting the gendered connotations of humanitarian assistance in protracted refugee situations in first countries of asylum (see Hyndmann and Giles, 2011). Although entry restrictions have been gradually introduced since 2014, leading to the closure of the border in 2015, Syrians who fled the armed conflict in their country are generally recognised in Jordan as refugees by the UNHCR. M any have regular residence permits, yet limited access to the formal job market and, thus, often precarious livelihoods. While the country hosts the biggest refugee camp in the Middle East, the vast majority of its internationally displaced population reside in urban areas such as Amman, Zarqa and M afraq, where our fieldwork was conducted (UNHCR, 2017). The choice was motivated not only by the severely restricted access to the government-controlled refugee camps, but also by the fact that refuge in urban areas requires that individuals and households actively mobilise to approach humanitarian actors. Through these agencies people encounter and relate with the Janus-faced humanitarian border, thus bringing into play the subjective dynamism of refugeeness.

To access the personal experiences of our participants, we carried out interviews and had ethnographic conversations on topics including the circumstances in which they had left their countries, their journeys including various distressing encounters yet also experiences of help and solidarity among migrants, ideas of borders and bordering practices, and relations with aid agencies, volunteers and other actors in hosting societies. Particularly in the case of Jordan, our learning as researchers has involved also letting ourselves be "draw(n) into relationships" in which our own embodiment reverberated with and mediated our informants' contradictory emotions (Bondi, 2005: 236). While all of the formal interviews focused on similar themes, our methodology has allowed specific 'matters of importance' chosen by each participant to emerge. This has ensured not only respect of confidentiality, but also that every informant has had the chance to actively draw their own personal and emotional boundaries when participating in the research. The topics addressed and the challenging and somewhat unpredictable nature of some of our ethnographic 
encounters raised a number of important ethical dilemmas. In dealing with them, we tried to make sure that all our participants have the opportunity to get in touch with us after the completion of fieldwork.

In Finland, where the more structured interview setting allowed for it, we started by describing how we understand the humanitarian border and why we want to study it, after which the participants were invited to tell about their personal trajectories. Instead of reasons for leaving, we directed the discussion towards their journeys through the Middle East and Europe, and the settling down and waiting periods. In Jordan, we focused on people's experiences of receiving financial and material help, as well as on their aspirations and approaches towards the procedures guaranteeing access to the few resettlement options available. Regardless of these emphases, the participants brought to the interviews and conversations many kinds of elements related to refugeeness and the humanitarian border, thus reflecting its topological constitution. In the Finnish study, three interviews were conducted in English, five in Arabic, and four in Farsi/Dari, with the help of interpreters in the latter two cases. ${ }^{1}$ In Jordan, fieldwork was conducted in Arabic and English, leaning on the longstanding ethnographic expertise of one of the authors (Pascucci) who has worked with refugees, international organisations and NGOs in Northern Africa and the Middle East since 2011, including ongoing research on humanitarian economies and innovation in responses to the Syrian refugee crisis within the Middle East.

\section{Experiencing the humanitarian border}

The study of the humanitarian border as a dynamic space, both governed and lived, faces two major challenges. One is to gain access to the ways in which people relate with the different refugee figurations that the border gives rise to, and the second is to grasp its complex and constantly transforming spatiality. In the subsequent analysis, we seek to meet these challenges by first introducing the expression of ambivalent emotions as a methodological entry point to studying refugeeness in the humanitarian border from experiential perspectives. Then, by discussing another empirical context in-depth, we will flesh out how the humanitarian border emerges as a dynamic topological space, where refugees encounter its various elements, actors and practices through emotional intensities.

\section{Ambivalent expressions of refugeeness}

We begin with an excerpt from field notes in the Jordan study, bringing forth ambivalent emotions about refugeeness as expressed by Dua'a, a 53-year-old Syrian woman. She shared her experiences, feelings, thoughts and attitudes with one of the authors (Pascucci) when they came across on a public bus that both were taking from Amman to visit a local charity in Zarqa. It was April 5 2017, the day after the chemical attack on the Syrian village of Khan Sheikhoun in the Idlib governorate. Perpetrated, according to the United Nations, by the Bashar al Assad regime, the attack "killed at least 83 persons, including 28 children and 23

\footnotetext{
${ }^{1}$ We have slightly edited the interview excerpts for readability, as none of our participants or interpreters were native English speakers, and in some places we provide clarifications to secure that the correct meaning is conveyed. To protect the anonymity of our participants we also use pseudonyms when referring to persons by name.
} 
women, and injured another 293 persons, including 103 children [...] symptoms suffered by victims is consistent with sarin exposure" (UN General Assembly, 2017: paragraph 75).

Introducing herself to the researcher sitting next to her, Dua'a hastened to express loudly and powerfully her pain and anger over the violence suffered by civilians in Khan Sheikhoun. In the immediate aftermath of the attack, sorrowful anger towards global powers was common among Syrians in Amman and Zarqa. Many expressed their mistrust towards what we might call the 'international community', including its humanitarian component, in public places such as Zarqa's markets, the screening of a documentary on Zaatari camp in Amman, or like Dua'a, in casual conversations. In her case, these feelings were clearly channelled through, and even enhanced by, the unexpected encounter with a Western researcher.

Dua'a despises the Syrian president as a 'kafir' (infidel), who studied and lived most of his life in the UK, as did his wife. She seems very upset, and even a bit off. I wonder what the people sitting around us think. She speaks breathlessly and just won't stop. "All Westerners are supporters of the Syrian regime, and the UNHCR and the NGOs and charities are just all a bunch of thieves, of criminals." When I explain some of the details of my job, Dua'a asks whether I know anyone at the UNHCR. She anxiously insists that I write down her and her families' details of registration. She demands that I assist her in finding help, particularly for her divorced daughter: "M aybe you can help her to be resettled abroad?" (Field notes, Jordan, 5 April 2017)

Besides lamenting the attack, Dua'a shared with the researcher her sense of victimisation in the Syrian war that had led to her exile already in 2012, and to what she perceived as inadequate humanitarian assistance, first in the Zaatari camp and currently at the peripheries of Amman. Showing how the humanitarian border constitutes as a sticky space difficult to pass through, her encounters with the system of humanitarian protection had brought Dua'a to identify humanitarian organisations as part of the same international community that had not only aggravated war in her country, but also deprived her of mobility. Yet, at the next instance, she insisted on further help from aid agencies through the researcher's mediation and advocacy, as she was travelling to meet with one of the local charities to seek help for her family. Dua'a clearly saw the researcher she had just met as part of a global configuration of arbitrary help and structural oppression, but also as a potential resource, thus highlighting the entanglement of academic research, media, and humanitarian apparatuses that we have explored elsewhere (Pascucci, 2017). These contradictions, and their strong emotional charge, highlight the ambiguity that characterises Dua'a's refugeeness.

The ambivalence that we identify in Dua'a's refugeeness is more than the coexistence of positive and negative emotional valences that a psychological reading might suggest (e.g. Basto et al. 2017). Rather, at play are dynamic and contextual feelings that emerge in the 'contact zone' between the subject's embodied experience and matrixes of power (Linke, 2006) - in this case between a Syrian refugee in Jordan, the geopolitics of the Syrian conflict, and the international refugee regime including migration control and humanitarian aid. Over 
the five years spent in Jordan, Dua'a has had no choice but to rehearse her refugeeness. Along with thousands of other forced migrants, she has had to relate with the figure of the refugee emerging from the ever-growing demand for protection due to the complex and violent conflict in the region, and the changing practices through which the international refugee regime seeks to meet these demands. The question on resettlement options for her divorced daughter that Dua'a asks at the end of the encounter, is particularly telling. It highlights the paradoxes of trying to fit into a system of humanitarian governance in which being a 'worthy' refugee means accepting immobility in the first country of asylum, and adapting to gendered categorizations of vulnerability (Hyndman and Giles, 2011).

Importantly, however, refugeeness here is about subjective relations with refugee identity experienced personally and at times shared with others, not about an identity imposed upon and circumscribing the subject. This open-endedness finds its expression in ambivalent emotions concerning the refugee position itself, which in our conceptualisation stands for refugeeness as political subjectivity. Tellingly, such ambivalence has been commonly present in our interactions with asylum seekers both in Jordan and in Finland. In our discussions, it typically surfaced as an openly or implicitly expressed ambiguity between being and notbeing a refugee (see also Sánchez, 2012). For example, in our Finnish study, Rahim was overtly struggling with the refugee identity. He first conveyed that, when introducing himself to Finnish people, he tells them "I'm from Iraq, from Baghdad and I'm a refugee. I'm really honest about that." Then Rahim reflected upon how this identity, which he chooses to pursue, feels uncomfortable: "Refugee is like ugly word to say. [...] I'm human like anyone here. [...] I don't wanna be like a refugee. I hate it. But this is my choice, so that's why I keep it also, I should say it."

Such ambiguity was at its most evident in the complex negotiations between transnational connections and aspirations related to family and work, and humanitarian aid and resettlement. Abu Ahmad, an engineer from the Syrian Golan in his fifties and living in Zarqa, expressed his desire to reunite with his sons and daughters living in Germany, to help them to settle there and find jobs. While most of his energies were focused on maintaining his family connections across continents and worrying about his children finding a job, he had some reluctant and bitter comments on their condition as refugees in Europe, too. Germany is "the only country", he explained, "where Syrians were treated as people". Heba, a 25year-old woman we met at a training workshop offered by an international NGO in Western Amman, voiced her aspiration to obtain a student visa to Canada, but also to keep her family's application for resettlement through the UN open. For her, as for many other young Syrians, refugeeness was both strongly re-affirmed in relation to the geopolitical situation in their country and carefully negotiated in individual and family trajectories related to labour, finances and mobility (Pascucci, 2018; see also Kallio, 2018; Kallio and Häkli, 2018). Others faced a similar kind of ambiguity in Jordan when confronted with the question of labour market integration. They feared that regularising their position as workers or looking for a job would lead to the withdrawal of the cash assistance they received from the UNHCR. This constant search for feasible means reveals the topological stickiness of the humanitarian border durably yet unevenly present in refugee lives. 
The stances that our research participants expressed mark political subjectivity that holds important capacities to agency in the humanitarian border, as will be discussed further in the next section. Far from being impeded by the uneven and 'ad-hoc' ways in which humanitarian aid is distributed in places of displacement (Dunn, 2012), people at once proclaim vulnerability and need for help, and project themselves as opinionated refugees, who do not think highly of the humanitarian aid system. Besides revealing the ambivalence of refugeeness, this open-ended relatedness with the figure of the refugee provides asylum seekers with the possibility to act in unexpected and even controversial ways, and thereby produce fissures in what otherwise might seem a ubiquitous regime of migration control.

Fractured humanitarian bordering in the Western Balkans route

To discuss how the topological humanitarian border emerges in refugees' encounters with it, including the transformative potential of refugeeness, we next focus on an empirical site of intensive emotions that most of our research participants brought up when describing their travel to Finland. This is the so-called 'Western Balkans route' and, more particularly, the Hungarian borderlands as its critical chokepoint during the 2015 mass arrival of refugees in Europe.

The number of recorded border crossings along the Balkans route started to rise when asylum seekers fleeing the war in Syria, and the generalised insecurity of Iraq and Afghanistan, started to travel in large numbers towards Western Europe. People travelled from Turkey to Greece, through M acedonia and Serbia, finally seeking to cross through the EU member countries Hungary and Croatia, which have been particularly unwelcoming to people seeking international protection.

The Hungarian border, especially towards the south, is currently among the strongest manifestations of territorial boundaries in Europe. Since 2015, it has acquired a major role as an element of migration control in the humanitarian border, in reflection of the Hungarian government's reluctance to receive asylum seekers and grant them international protection. This unwelcoming policy culminates in legislation that has been passed in Hungary in 2017, with all asylum seekers having to go through a mandatory detention in high-security container camps, after which they are made to return to where they came from, or just leave Hungary. Further restrictions to asylum seeking, including criminalisation of all aid, have been made by the Hungarian government in 2018.

From our perspective, it is critical to understand how the route was established and how its development influenced the formation of refugeeness among those who were travelling it. Our study participants, who travelled to Finland through the Western Balkans route in September 2015 when the Hungarian border control was already being hurriedly tightened, discussed the site in very negative terms; they had found out there what becoming a refugee means in its worst. This is how Samer, an Iraqi man in his early twenties, describes the asylum policy and bordering practices he faced in Hungary.

The government of Hungary sees someone, will take him to camp and put fingerhands [fingerprints]. If you put your fingerprints, it's, no country any more will accept you, just Germany. Then, I was really really afraid from that problem. But I see many people go 
walking inside the forest, go away from this government or this army. I try to do that, go to the forest. [...] Then, I got to park for cars. The driver told me, I want from every person 250 euro. I say, OK, no problem. Just take me away from this army to Budapest. And he say OK. He take [me] to Budapest. From Budapest, every government, every police look to me and just... if I do something wrong they will take me, to put my fingerprints. Then I try to be really quiet and I go by easy, easy. Then I go to train station. I take train from Budapest to Austria.

Far from a simple border crossing, Samer's experience shows how the humanitarian border constitutes as a topological space conditioning refugee trajectories. For Samer, as for other asylum seekers, being registered in Hungary would have prevented them from seeking asylum in other EU countries due to the Dublin III Regulation. As Hungary did not grant asylum either, being caught by local border guards or police could have meant the end of their efforts to gain a legal position tout court. Awareness of this risk was largely shared across refugee communities and, as Samer expressed, raised deep anxiety and fear. These emotions were intertwined with other feelings, such as worry about having to turn back, but also hopes regarding the possibility to access Western European countries. The ambivalence related to what becoming a refugee means and entails for the people on the move is part and parcel, we argue, of how the humanitarian border manifested in the Western Balkans route during 2015.

To grasp this development, it is useful to turn to a piece of narrative from an interview with Akram, one of our Iraqi participants, who described his border experience as the coming together of fear, solidarity, help, and exploitation. He began his account by discussing how he, travelling with his younger brother, had learned about the Hungarian migration regime.

We went to the border of Hungary. There was a small village there, and the Red Cross camp, near the border. There was a lot of people sitting in that camp. They get food, water, shower. There in the border we, me and my brother, were asking the people, "Take us to cross the Hungary border." That was difficult because the police and army were everywhere, in Hungary. But everyone we ask they look like, "We don't, we are not comfortable with [the smugglers]. They are like a gang or something. They are dangerous people." We can see [the suspicion] from their behaviour, from their faces. And we went walking from that place about two kilometres to the border. There we see some police who told us "You can go. You can cross the border." And we just, "Is it that easy? It's not possible." And then one of the journalists told us, "Where are you from?" We said, "From Iraq." And they said, "Don't cross the border. It's not safe. In Hungary they just take your fingerprints and let you in the street." [...] And then we find a family there, in the borders behind one tree, they looked like they are planning to cross the border by themselves. Me and my brother just went to them, "Are you going to cross the border, alone?", and they said, "Yeah." "Can we come with you?", and they said, "Okay." 
In his opening account, Akram already points at several actors participating in the realisation of the humanitarian border, most with palpable emotional underpinnings. Among these is the Red Cross that all our participants took up as an unfailing provider of humanitarian help, responsive to their different vulnerabilities and often treating refugees in a respectful and soothing manner. With more disquiet, Akram talks about the fellow travellers in the aid camp who conveyed fear towards the smugglers, as well as the border police who seemed to be motivated by the Hungarian government's migration control rather than the provision of humanitarian protection. Third, Akram recalls sympathetically the journalists who advised him and his brother not to cross the border, expressing unselfish care for their safety. Finally, as an unanticipated turn he mentions the Syrian family preparing to cross the border and welcoming the young Iraqi men to join them without claims or requests.

All these emotion-laden encounters between actors drawn to the humanitarian border make visible not only the multifarious constellation that refugeeness is when negotiated 'on the ground', but also Akram's own agency that includes helping the family and taking care of his younger brother, and requesting and receiving help from others. He describes the family's strategy as follows:

They have no experience but they have someone to guide them by phone. Because their cousin, two months ago before them, they went this way and they give them instructions on what to do. He's in contact with his cousin, to tell him where to go, and in the same time other phone put GPS. "Go this way you find this and this, cornfield and you find this, some kind of building." It was exact information about the place where we are.

New elements of the humanitarian border appear here, with the Syrian family preparing to cross the border by means of instructions at distance guiding them through the route that a European-based relative had taken previously. In Akram's view the familial assistance based on sharing experiential knowledge was very efficient, leading them to the right direction.

Before we cross, there was wires and we found some Serbian people there. They offer to help us, but with money. "Give us 50 euro and we will help you to cross the border." We said "Okay." When we found that fence, they just lifted it up and we run from behind that. When we cross, police start to look for us, Hungary police, they are everywhere, dogs and cars and we heard them. Then helicopter look for us from up, and we are hiding in the fields and we couldn't move, with this family. But the family, their kids they just get tired and we just sit in the cornfield. And then it start to rain and it was very cold there. We start to shake from the cold. We were wet and the child, they start to cry. The youngest one was two to three years, and the other like maybe five to six years. We walk for 50 kilometres in the fields. 
Akram's account of the chain of events was very emotional, expressed not only verbally, but also with his tone of voice, facial expressions, bodily gestures, and his alert and anxious appearance (see also Williams and Boyce, 2013). Indeed, the whole situation had been characterised by the presence of ambivalent feelings ranging from distress caused by the loud and seemingly endless presence of the Hungarian police, a string of hope attached to the possibility of crossing through for a small fee, and despair as the children were crying from fatigue. Yet, Akram also expressed shared vulnerabilities and compassion. While he and his brother were surely exhausted by the events, their troubles could not compare with those of the young children who had to go through the same trial. Put together with the fact that the Syrian family were helping Akram and his brother - letting them to join in and sharing with them their kinship network and devices that enabled the traverse through the borderland without smugglers - a manifold mesh of care can be identified (on familial refugee agency, see Kallio 2018; Kallio and Häkli, 2018).

The way in which these multiple emotions and agencies came together in Akram's case shows well how refugeeness is negotiated in a crossfire of equivocal and even contradictory figurations of the refugee. These are proposed by different actors of the humanitarian border in varying situations, including those responsible for the sorting regime, those seeking to provide institutional support, those offering help in any manner possible, and those who share the situation as fellow travellers. Scattered across space and time, the practices that constitute the humanitarian border coalesce it as a topological space that exists wherever it is practiced, experienced and enacted upon. M oreover, refugeeness is clearly not merely about individuated political subjectivity as all these formative relations are intersubjectively generated and in many ways collectively shared.

In this regard, it is important to note yet another facet in Akram's narrative that shows how refugeeness is about position taking not only in relation to the migration regime, but also to the communities that refugees pass through and live in:

When we get near [the Serbian-Hungarian border], some people just wait for us, and they offer us "Do you want taxi to Budapest?", and we said, "Okay." "Okay, for each person we have to get 250 euro." Hungarian people they exactly know how to use this situation there. [...] The Serbian people, they were just okay. And in Greece, people were nice. Macedonian people, the army was aggressive but I haven't seen anyone hit anyone. They are just trying to organise them to put them in the train, so that was normal to me; I see it's a mess and it's normal to yell [chuckles]. In Hungary, people wasn't friendly and they even don't smile. The family there in the fields, we send the kids to bring water and they didn't give the water to the kids. They just send them away because they're afraid of police or something.

In Akram's experience, the Hungarian people involved in the border crossing 'business' seemed indifferent and self-seeking, even compared to the Macedonian soldiers who were moving people through the country in a not-so-gentle manner. Hence, for him it was not only the Hungarian state, but also the Hungarian people actively appropriating the Western Balkans route, who were failing to acknowledge the refugees' vulnerabilities (cf. Williams 
and Bouce, 2013). The grim figure of the refugee thus proposed contrasted sharply with Akram's experience of arriving in Austria, where very different figurations were beginning to appear (on 'welcome', see Gill 2018):

We just walk to the border and we find, at least we feel like someone care about us, in Austria. There was big camps, it was the border control and they make tents there, they give food, they give everything. We were just in peace there.

With our broader analysis and close reading of Akram's narrative concerning the Western Balkans route at the Hungarian borderlands, we have sought to portray how experienced encounters with elements and actors of the humanitarian border incite political subjectivities in the form of refugeeness. The emerging implicit and explicit as well as cognitive and embodied forms of knowing provide capacities for refugees to encounter and act upon the humanitarian border as a lived relational space. The Western Balkans route is one recent fractured formation that emerged as a result of various institutional and mundane political agencies, including states, international organisations, smugglers, local people, journalists, activists, and refugees as important actors. While it obviously involves many topographically pertinent features and forms of governing that employ physical contact and proximity, our analysis shows that, as experienced by refugees the humanitarian border is socially constituted, engaging elements and actors from near and far, and pulling together political agencies motivated from within and beyond the state-based migration regime.

\section{Substantiating the topological humanitarian border: refugeeness and intensities}

This paper presents an attempt to explore the fluctuating geographies of the humanitarian border and to create better understanding of its spatial ambiguities. Acknowledging the Janus-faced character of humanitarian aid and the governmental mechanisms seeking to regulate and manage migration, we have approached humanitarian topologies from the perspective of refugee-subjects. The choice is motivated by our interest to shed light on refugees' political subjectivities and agencies, challenging a global system of proliferating and increasingly restrictive "labels" (Zetter, 2007; Ludwig, 2016). In this system, people's capacity to act and retain a multi-faceted sense of self is often held against them as fraudulent behaviour - as in the figure of the 'bogus asylum seeker' - rather than acknowledged as the product of the relations through which an increasingly global border is constituted. Our analysis shows that life as a refugee, with or without a formal status, requires from people various forms of active agency in order to survive and to retain their humanness (also Häkli et al. 2017; Kallio \& Häkli 2018; Pascucci et al. 2019).

Looking at the subtle emotional and embodied ways in which people relate with different figurations of the refugee unmasks the humanitarian border that tends to expand, diversify, become all encompassing, ubiquitous, ever more ambivalent and yet always more unstable and fractured in the present world. It is also, however, a problematic act that requires balancing accuracy and the ethical imperative not to make visible what migrant and refugee 
subjects might be trying to keep invisible, in order to preserve its efficacy. At the same time, it needs to avoid scrutinising emotions voyeuristically. The way we have handled ethnographic and interview material has been informed by an ethos aimed at exposing a border constellation that materialises through experiences, rather than valorise these experiences as such.

In our analysis, we introduced ambivalent emotions as an entry point to studying refugeeness from experiential perspectives. The ambivalence, which most of our research participants expressed in regard the humanitarian border at once potent and lacking as a source of support, testifies to the open-endedness of refugeeness as political subjectivity. As M cNevin (2013: 182) has argued, ambivalence can act "as political resource that is generative of new political relations across the terrain of human mobility and border control". Adding humanitarian aid to this equation, we wish to make two suggestions, regarding the study of refugeeness as political subjectivity, and the topological theorisation of the humanitarian border.

First, in analysing refugeeness as a distance between one's sense of self and the figure of the refugee, we have found that these political subjectivities involve ambivalent emotions that people struggle with, yet draw from, in their attempts to act in tactical and strategic ways within the humanitarian border. All refugees confront the humanitarian border through certain (regime-grounded) expectations, but their experiences vary due to the fundamental plurality and varying stickiness of the humanitarian border that takes completely different forms in distinct situations. While many aspects deserve attention, in our study mobility stood out as a dimension of consequence to refugeeness.

While Dua'a encountered no physical manifestation of borders in her daily life in Jordan, for her asylum and assistance came at the price of immobilisation. Leaving Jordan on one's own often means losing entry and residence rights in the country for good, and can involve exposing oneself to dangerous and expensive irregular journeys. Hence, her refugeeness is built in relation to bordering mechanisms combining the provision of support with social sorting and immobilisation. Dua'a's enquiry about the possibility of resettlement for her daughter foregrounds her awareness of the situation. As a divorced woman and a single mother, her daughter has the chance to be recognised as a particularly vulnerable refugee with the best possibility for international mobility in her family.

The Western Balkans route, instead, was characterised by mobility in 2015. This facet of the humanitarian border, as experienced by Samer, Akram and thousands of others, appeared in the form of a flow of people heading to the same direction, on their way to seek asylum and find new life opportunities in the EU. Many institutional and mundane actors were involved in the mass movement from Turkey and Greece, through Macedonia and Serbia, passing through either Hungary or Croatia, and continuing in Western and Northern European countries. Yet other actors were seeking to hinder the movement and push the refugees back ever more forcefully, thinning out the route considerably after 2015. In the process, the Western Balkans route itself became part of the humanitarian border, involving fluctuating practices of care and control, and shaping forcefully people's experiences of refugeeness as the basis of their transformative agencies. 
Second, regarding the relational spatialities of the humanitarian border, we wish to heed the call to interrogate topological relations "in ways that reach beyond the importation of a mathematical heuristic into social thought", recognising that "[at] the border there is a certain intensification of political and even existential stakes that crystallize relations of domination and exploitation, subjection and subjectivation, power and resistance" (Mezzadra \& Neilson, 2012: 60). In this spirit, we have paid particular attention to the ways in which refugeeness as a political subjectivity finds expression in various kinds of emotional intensities that reveal when, how, and for whom the humanitarian border comes into existence in the form of relationships that create proximities between "the powerful and not so powerful actors" (Allen, 2012: 284). The fluctuating intensities of humanitarian bordering hence appear as manifold and ambiguous, and by tracing these different kinds of intensifications from experiential as well as governmental perspectives, it is possible to gain a better understanding of the 'power topology' of the humanitarian assistance-migration control nexus.

\section{Acknowledgements}

Our research would not have been possible without the people who participated in our research and helped us otherwise, including the refugee participants, the interpreters Ali Sabr and Negin Armioun, and the staff of the HumBORDER project at the Peace Research Institute Oslo, sincere thanks to you all. We also wish to thank the editors of EPC and the two anonymous referees for a supportive process. Special thanks to Nick Gill for helpful comments at the Finnish Geographers Annual M eeting, and to Banu Gökarıksel for valuable feedback at the AAG 2018 and during our visit at the University of North Carolina at Chapel Hill. Finally, we are grateful to the Space and Political Agency Research Group (SPARG) at the University of Tampere for an inspiring research environment.

\section{References}

Ahmed S (2004) The Cultural Politics of Emotion. Edinburgh: Edinburgh University Press.

Baines EK (2015) “Today, I want to speak out the truth": victim agency, responsibility, and transitional justice. International Political Sociology 9(4): 316-32.

Basto I, Pinheiro P, Stiles WB, Rijo D and Salgado J (2017) Changes in symptom intensity and emotion valence during the process of assimilation of a problematic experience: $A$ quantitative study of a good outcome case of cognitive-behavioral therapy. Psychotherapy Research 27(4): 437-449.

Bayat A (2010) Life as Politics. How Ordinary People Change the Middle East. Amsterdam: Amsterdam University Press.

Bondi $L$ (2005) The place of emotions in research: From partitioning emotions and reason to the emotional dynamics of research relationships. In: Davidson JD, Bondi L and Smith M (eds) Emotional Geographies. Farnham: Ashgate, pp.231-46. 
DarlingJ (2009) Becoming bare life: asylum, hospitality, and the politics of encampment. Environment and Planning D: Society and Space 27(4): 649-65.

Dunn EC (2012) The chaos of humanitarian aid: adhocracy in the Republic of Georgia. Humanity 3(1): 1-23.

de Vries LA (2016) Politics of (in) visibility: governance-resistance and the constitution of refugee subjectivities in Malaysia. Review of International Studies 42(5): 1-19.

Diken B and Laustsen CB (2005) The Culture of Exception: Sociology Facing the Camp. London: Routledge.

Gill N (2018) The suppression of welcome. Fennia 196(1): 88-98.

Grabska K (2006) Marginalization in urban spaces of the global south: Urban refugees in Cairo. Journal of Refugee Studies 19(3): 287-307.

Hadjiyanni T (2002) The Making of a Refugee: Children Adopting Refugee Identity in Cyprus. Westport, Conn: Praeger.

Häkli J and Kallio KP (2014) Subject, action and polis: Theorizing political agency. Progress in Human Geography 38(2): 181-200.

Häkli J and Kallio KP (2018) On becoming political: The political in subjectivity. Subjectivity 11(1): 57-73.

Häkli J, Pascucci E and Kallio KP (2017) Becoming refugee in Cairo: The political in performativity. International Political Sociology 11(2): 185-202.

Holmes M (2015) Researching emotional reflexivity. Emotion Review 7(1): 61-66.

Hyndmann J and Giles W (2011) Waiting for what? The feminization of asylum in protracted situationsl. Gender, Place and Culture 18(3): 361-379.

Ilcan S and Rygiel K (2015) "Resiliency humanitarianism": responsibilizing refugees through humanitarian emergency governance in the camp. International Political Sociology 9(4): 333351.

Isin E (2012) Citizens without Frontiers. London: Continuum.

Kallio KP (2018) Leading refugee lives together: Familial agency as a political capacity. Emotion, Space and Society. [Early View] https://doi.org/10.1016/j.emospa.2018.08.002

Kallio KP and Häkli J (2017) Geosocial lives in topological polis: Mohamed Bouazizi as a political agent. Geopolitics 22(1): 91-109.

Kallio KP and Häkli J (2018) Care as mundane politics in contested familial refugee lives. Gender, Place and Culture. [in press]

Lacroix M (2004) Canadian refugee policy and the social construction of the refugee claimant subjectivity: understanding refugeeness. Journal of Refugee Studies 17(2): 147-66. 
Latif N (2008) M aking Refugees. CR: The New Centennial Review 8(2): 253-72.

Lee M (2013) Human trafficking and border control in the global south. In: Franko Aas K and Bosworth M (eds.) The Borders of Punishment: M igration, Citizenship, and Social Exclusion. Oxford: Oxford Scholarship Online, pp. 128-149.

Linke U (2006) Contact zones: rethinking the sensual life of the state. Anthropological Theory 6(2): 205-225.

Little A and Vaughan-Williams N (2016) Stopping boats, saving lives, securing subjects: humanitarian borders in Europe and Australia. European Journal of International Relations [online advance publication]

Ludwig B (2016) "Wiping the refugee dust from my feet": advantages and burdens of refugee status and the refugee label. International M igration 54(1): 5-18.

Luker T (2015) Performance anxieties: interpellation of the refugee subject in law. Canadian Journal of Law and Society 30(1): 91-107.

M cNevin A (2013) Ambivalence and citizenship: Theorizing the Political Claims of Irregular M igrants. M illennium: Journal of International Studies 41(2): 182-200 DOI:

$10.1177 / 0305829812463473$

M igri (2017) Statistics on asylum and refugees. Availabe at:

http://www.migri.fi/about_us/statistics/statistics_on_asylum_and_refugees (accessed 24 May 2017)

Mitchell K and Sparke M (2018) Hotspot geopolitics versus geosocial solidarity: contending constructions of safe space for migrants in Europe. Environment and Planning: Society and Space. https:// doi.org/ 10.1177/0263775818793647

M ountz A (2015) In/visibility and the securitization of migration: shaping publics through border enforcement on islands. Cultural Politics 11(2): 184-200.

M urphy AB (2012) Entente territorial: Sack and Raffestin on territoriality. Environment and Planning D: Society and Space 30(1): 159-172.

Nyers P (1998) Refugees, humanitarian emergencies, and the politicization of life. Refuge: Canada's Journal on Refugees 17(6): 16-21.

Olivius E (2014) (Un)governable subjects: the limits of refugee participation in the promotion of gender equality in humanitarian aid. Journal of Refugee Studies 27(1): 42-61.

Ong A (2003) Buddha is Hiding: Refugees, Citizenship, the New America. Berkeley: University of California Press.

Owens P (2012) Human security and the rise of the social. Review of International Studies 38(3): 547-67. 
Pascucci E (2017) The humanitarian infrastructure and the question of over-research: reflections on fieldwork in the Middle Eastern refugee crises 2011-2015. Area 49(2): 249-255.

Pascucci E (2018) Refugees in the IT sector: Young Syrians' economic subjectivities and familial lives in Jordan. The Geographical Review [in press]

Pascucci E, Häkli J and Kallio KP (2019) "Delay and neglect": The everyday geopolitics of humanitarian borders. In Paasi A, Prokkola EK, Saarinen J and Zimmerbauer K (eds.) Borderless Worlds - For Whom? Ethics, M oralities and M obilities. London: Routledge. ISSN: 9780815360025. [in press]

Rossdale C (2015) Occupying subjectivity: being and becoming radical in the twenty-first century: introduction. Globalizations 12(1): 1-5.

Rygiel K (2011) Bordering solidarities: migrant activism and the politics of movement and camps at Calais. Citizenship Studies 15(1): 1-19.

Sánchez ME (2012) The reconfiguration of subjectivity and of intersubjective relations in migratory processes: A case study. International Forum of Psychoanalysis 21(3-4): 159-166.

Soguk N (1999) States and Strangers. Refugees and Displacements of Statecraft. M inneapolis: University of Minnesota Press.

Stierl M (2017) A Fleet of mediterranean border humanitarians. Antipode [online advance publication]

Tazzioli M (2016) Border displacements. Challenging the politics of rescue between Mare Nostrum and Triton. Migration Studies 4(1): 1-19.

UNHCR (2017) Syria Regional Refugee Response. Available at:

http://data2.unhcr.org/en/situations/ syria (accessed 31 May 2018)

Verdirame $G$ and Harrell-Bond BE (2005) Rights in Exile: Janus-Faced Humanitarianism. Oxford: Berghahn Books.

Walters W (2008) Acts of Demonstration: Mapping the Territory of (Non-)Citizenship. In: Isin E and Neilson GM (eds) Acts of Citizenship. London: Zed Books, pp. 182-206.

Walters W (2011) Foucault and frontiers: notes on the birth of the humanitarian border. In: Bröckling U, Krasmann S and Lemke T (eds) Governmentality: Current Issues and Future Challenges. New York: Routledge, pp. 138-164.

Walters W and Lüthi B (2016) The politics of cramped space: dilemmas of action, containment and mobility. International Journal of Politics, Culture, and Society 29(4): 359-366.

Williams JM (2016) The safety/security nexus and the humanitarianisation of border enforcement. The Geographical Journal 182(1): 27-37. 
Williams J and Boyce GA (2013). Fear, loathing and the everyday geopolitics of encounter in the Arizona borderlands. Geopolitics 18(4): 895-916.

Zetter R (2007) M ore Labels, Fewer Refugees: Remaking the Refugee Label in an Era of Globalization. Journal of Refugee Studies 20(2): 172-192.

https://doi.org/10.1093/jrs/fem011 